\title{
KECENDERUNGAN KORBAN PELECEHAN SEKSUAL DI TEMPAT KERJA DITINJAU DARI TIPE KEPRIBADIAN PADA WANITA MINANG
}

\section{TYPES OF PERSONALITY AND TENDENCY TO BE VICTIMS OF SEXUAL HARASSMENT IN THE WORKPLACE}

\author{
Rida Yanna Primanita ${ }^{1}$, Suci Rahma Nio ${ }^{2}$, Vira Yuliani ${ }^{3}$ \\ Jurusan Psikologi FIP, Universitas Negeri Padang/yannaprimanita@ fip.unp.ac.id
}

\begin{abstract}
Introduction Types of personality and tendency to be victims of sexual harassment in the workplace. The purpose of this research is to see the tendency of the victims of sexual harassment towards women workers in terms of personality types in West Sumatra.
\end{abstract}

Method This research is a comparative quantitative type and analyzes using statistical techniques of non-parametric difference test. The population of this research is Minang ethnic women who work in West Sumatra and experience sexual harassment at work, using snowball sampling techniques. The research instrument uses the sexual harassment scale and Myers Brigss Type Inventory.

Results Based on the results, the value of Sig $=0.052$ (Sig <0.05), it means that there is no significant difference in the level of sexual harassment experienced by Minang ethnic women in the workplace in terms of their personality types. The result also shows that the majority of ethnic Minang women in this research experienced sexual harassment in the workplace in the medium category.

Conclusion and Recommendation Based on the results of research and hypothesis, it can be concluded The level of sexual harassment in the workplace experienced by Minang ethnic women is in the medium category, and There is no level of sexual harassment in the workplace experienced by Minang ethnic women based on their personalities. Minang ethnic women are suggested to be more careful in establishing relationships at work, as well as increase their knowledge about forms of sexual harassment and ways to minimize it. The workplace owners are expected to have clear and firm regulations on sexual harassment behavior in the working area. The next reseach is suggested to continue research related to the theme of sexual harassment in Minang ethnic women by using other variables which are assumed to be related to sexual harassment behavior.

Keywords: sexual harassment, women workers, Minang, Myers Briggs personality type

\begin{abstract}
ABSTRAK
Pendahuluan Tipe kepribadian dan kecenderungan menjadi korban pelecehan seksual di tempat kerja pada wanita etnis Minang. Penelitian ini bertujuan untuk melihat kecendrungan menjadi korban pelecehan seksual pada wanita bekerja ditinjau dari tipe kepribadian di Sumatera Barat.

Metode Penelitian ini berjenis kuantitatif komparatif dan dianalisa menggunakan teknik statistika uji beda non-parametric. Populasi penelitian ini adalah wanita etnis Minang yang bekerja di Sumatera Barat yang mengalami pelecehan seksual di tempat kerja, dengan teknik pengambilan sampel snowball. Instrumen penelitian yang digunakan skala sexual harassement dan Myers Brigss Type Inventory.
\end{abstract}


Hasil Berdasarkan hasil perhitungan diperoleh nilai $\operatorname{Sig}=0,052(\operatorname{Sig}<0,05)$, artinya tidak terdapat perbedaan yang signifikan pada tingkat pelecehan seksual yang dialami wanita etnis Minang di tempat kerja ditinjau dari tipe kepribadiannya.

Kesimpulan dan Saran. Berdasarkan hasil penelitian dapat disimpulkan bahwa tingkat pelecehan seksual di tempat kerja yang dialami wanita etnis Minang berada pada kategori sedang, dan tidak terdapat tingkat pelecehan seksual di tempat kerja yang dialami wanita etnis Minang berdasarkan tipologi kepribadian yang dimiliki. Bagi wanita etnis Minang disarankan untuk dapat lebih meningkatkan kehati-hatiannya dalam menjalin relasi di tempat kerja, serta meningkatkan wawasan mengenai bentuk-bentuk pelecehan seksual dan cara untuk meminimalisir hal itu terjadi pada diri sendiri.

Kata kunci : Pelecehan seksual, wanita bekerja, etnis Minang, tipe kepribadian Myers Briggs

\section{Pendahuluan}

Wanita beraktivitas dalam dunia kerja bukanlah hal baru. Dalam praktiknya banyak wanita yang memperoleh posisi ataupun tugas yang bergengsi seperti pekerja laki-laki. Perbandingan beban pekerja laki-laki dengan beban kerja wanita bukan hanya berkaitan dengan tugas atau pekerjaannya sehari-hari. Namun juga wanita memiliki masalah pada seksual dan gender, salah satunya berkaitan dengan pelecehan.

Wanita lebih rentan mengalami pelecehan seksual dibandingkan laki-laki. Hal ini dibuktikan lewat survei di tempat kerja yang terjadi di Amerika serikat, 1 dari 18 wanita dan 1 dari 40 pria mengalami pelecehan seksual yang dilakukan oleh bos, supervisor, rekan kerja, bahkan kliennya (Awaliyah \& Nuroyo, 2010). Sedangkan di Indonesia, survey yang dilakukan Koalisi Ruang Publik Aman menemukan bahwa tiga dari lima perempuan dan satu dari sepuluh laki-laki mengalami pelecehan di ruang publik (Awaliyah \& Nuroyo, 2010). Bagi masyarakat minang Sumatera Barat, wanita minang berkarir ikut bekerja mencari uang bukanlah suatu hal baru dalam sistem budaya matrilineal yang dianut masyarakat Sumatera Barat. Wanita dalam budaya minang sangat dimuliakan, dimana wanita sebagai penentu garis keturunan, peran dan kontribusi wanita dalam sebuah pengambilan keputusan keluarga sangat penting, wanita Minang juga terlibat aktif berupaya memenuhi perekonomian keluarga.
Sistem nilai yang memuliakan perempuan dalam adat Minangkabau memiliki konsekuensi dimana wanita yang bekerja di Sumatera Barat akan mendapatkan perlakuan yang baik dan dihargai oleh orang-orang yang berada di lingkungan kerjanya.

Dalam realitas sehari-hari, peneliti juga menemukan bahwa wanita yang berkerja di Sumatera Barat juga rentan mengalami pelecehan seksual di tempat kerja, walaupun kasusnya jarang di beritakan dan dilaporkan kepada pihak berwajib.

DPS (33 tahun), pernah bekerja di salah satu BUMN cabang kota Bukittinggi. Ia mempunyai sifat yang cukup menyenangkan dan tidak ragu untuk berkomunikasi mengutarakan pendapat kepada orang lain. Dia mengalami pelecehan seksual secara lisan, isyarat dan tertulis dari atasannya. Respon yang ia tampilkan selama peristiwa itu terjadi adalah membiarkan karena khawatir dengan kelangsungan karirnya di BUMN tersebut. Peristiwa itu berlangsung selama kurang lebih 6 bulan hingga akhirnya ia mengundurkan diri lalu melaporkan kasus itu pada pihak berwajib untuk ditindaklanjuti.

M (26 tahun) pernah menjadi tenaga kontrak di BUMN cabang Padang. Ia tipikal yang ramah namun tidak menonjolkan diri. Ia mengalami pelecehan seksual di kantornya terdahulu oleh rekan seniornya berupa rayuan dan tingkah laku yang mengandung unsur seksual. Akibat 
dari hal itu, ia menjadi tidak fokus di tempat kerja, seringkali menghindar bekerja dalam satu tim dengan rekan senior tersebut, sehingga pada saat berakhirnya masa kontrak kerjanya, ia memutuskan tidak memperpanjangnya.

Dari data ini dapat kita pahami bahwa pelecehan seksual dapat terjadi dimana saja terutama dalam lingkungan kerja. Pelecehan seksual yaitu semua tingkah laku seksual atau kecenderungan untuk bertingkah laku seksual yang tidak diinginkan oleh orang lain baik psikologis atau fisik yang menurut si penerima tingkah laku sebagai merendahkan martabat, penghinaan, intimidasi, atau paksaan (Sihite, 2007). Menurut Winarsunu (Winarsunu, 2008). pelecehan seksual adalah segala bentuk perilaku yang berkonotasi seksual yang dilakukan secara sepihak dan tidak dikehendaki oleh korbannya. Bentuknya dapat berupa ucapan, tulisan, simbol, isyarat dan tindakan yang berkonotasi seksual. Aktifitas yang berkonotasi seksual bisa dianggap pelecehan seksual jika mengandung unsur-unsur sebagai berikut, yaitu adanya pemaksaan kehendak secara sepihak oleh pelaku, kejadian ditentukan oleh motivasi pelaku, kejadian tidak diinginkan korban, dan mengakibatkan penderitaan pada korban (Winarsunu, 2008). Pelecehan seksual yang dihadapi laki-laki maupun perempuan dalam berbagai bentuknya, mulai dari komentar yang berkonotasi seksual dan kontak fisik secara tersembunyi (memegang, atau sentuhan ke bagian tubuh tertentu) hingga ajakan yang dilakukan secara terangterangan, dan seksual yang agresif (Santrock, 20193). Fitzgerald (Fitzgerald, et.all, 1999). Penjelaskan perilaku pelecehan seksual dalam tiga dimensi yang saling berkaitan namun berbeda, yaitu: (a) Gender harassment, perilaku pelecehan seksual yang mengarah pada perilaku merendahkan atau menghina dikarenakan gender seseorang, (b) Unwanted sexual attention, perilaku pelecehan seksual yang mengarah pada perilaku menarik perhatian yang tidak dinginkan, tidak dibalas dan menyinggung. Seperti perilaku memperlihatkan alat kelamin di depan umum, perilaku menggoda seseorang dengan panggilan mesra, perilaku menggoda seseorang dengan menggunakan bahasa tubuh atau mimik wajah, perilaku mencolek atau memegang tubuh orang lain dan perilaku bercanda atau bercerita hal seksual, dan (c) Sexual coercion, perilaku pelecehan seksual yang lebih mengarah pada perilaku memaksa, memeras, atau memberikan iming-iming atau hadiah untuk memperoleh aktivitas seksual bersama.

Hasil penelitian sebelumnya menemukan bahwa salah satu faktor penyebab terjadinya pelecehan seksual di kantor adalah karakteristik korban (Dwiyanti, 2014). yang lebih memilih mendiamkan peristiwa tersebut atau menghindar, serta merasa bahwa peristiwa itu tidak akan ditindaklanjuti jika dilaporkan. Karakteristik merupakan segala bentuk tingkah laku yang ditampilkan seseorang dalam kesehariannya atau disebut juga dengan tipe kepribadian, Carl Gustav Jung mendefinisikan tipe kepribadian sebagai totalitas segala peristiwa psikis yang disadari ataupun tidak disadari.

Tipe kepribadian Myers-Brigss yang akan digunakan dalam penelitian ini dikembangkan oleh Katharine Briggs dan anaknya Isabel Briggs Myers. MBTI bersandar pada empat dimensi utama yang saling berlawanan (dikotomis) (MBTI, 2018). Berikut empat skala kecenderungan MBTI:

1. Extrovert (E) vs Introvert (I). Dimensi EI melihat orientasi energi ke dalam atau ke luar. Ekstrovert artinya tipe pribadi yang suka dunia luar. Sebaliknya, tipe introvert adalah yang suka dunia dalam (diri sendiri).

2. Sensing (S) vs Intuition (N). Dimensi SN melihat bagaimana individu memproses data. Sensing memproses data dengan cara bersandar pada fakta yang konkrit, praktis, realistis, dan melihat data apa adanya. Sementara tipe Intuition memproses data dengan melihat pola dan 
hubungan, pemikir abstrak, konseptual serta melihat berbagai kemungkinan yang bisa terjadi.

3. Thinking (T) vs Feeling (F). Dimensi TF melihat bagaimana orang mengambil keputusan. Thinking adalah yang selalu menggunakan logika dan kekuatan analisa untuk mengambil keputusan. Sementara Feeling adalah yang melibatkan perasaan, empati, serta nilainilai yang diyakini ketika hendak mengambil keputusan.

4. Judging (J) vs Perceiving (P). Dimensi JP melihat derajat fleksibilitas seseorang. Judging diartikan sebagai tipe orang yang selalu bertumpu pada rencana yang sistematis, serta senantiasa berpikir dan bertindak teratur (tidak melompatlompat). Sementara tipe perceiving adalah yang bersikap fleksibel, spontan, adaptif, dan bertindak secara acak untuk melihat beragam peluang yang muncul.

Dari empat dimensi yang saling bertolak belakang ini, maka akan terbentuk tipe-tipe kepribadian ISTJ, ISFJ, ISTP, ISFP, INTJ, INFJ, INTP, INFP, ESTJ, ESFJ, ESTP, ESFP, ENTJ, ENFJ, ENTP dan ENFP.

\section{Metode Penelitian}

Penelitian tahap awal ini merupakan penelitian kuantitatif deskriptif dengan variabel terikatnya adalah kecenderungan menjadi korban pelecehan seksual dan variabel bebasnya adalah tipologi kepribadian Myers Briggs. Populasi dalam penelitian ini adalah wanita etnis Minang yang bekerja di luar rumah (instansi pemerintah/ perusahaan/ lembaga) di provinsi Sumatera Barat. Teknik sampling yang akan digunakan ialah snowball sampling sehingga jumlah sampel dalam penelitian ini sebanyak 185 orang.

Instrumen pengumpul data yang digunakan dalam penelitian ini adalah skala sexsual harassement yang dimodifikasi dari skala Sexual Experience Questionnaire (SEQ-DOD) yang dirancang oleh Kurnianto tahun 2016 berdasarkan alat ukur yang dibuat oleh Fiztgerald. Item semula sejumlah 33 item, namun yang digunakan dalam penelitian ini sejumlah 24 item, masing-masing dimensi terwakili dengan 8 item. Item yang digunakan adalah item yang memiliki nilai $r$ hitung $>0,25$, dan skala ini memiliki nilai $\alpha=0,855$. Untuk mengukur tipe kepribadian menggunakan Myers Briggs Type Inventory, dengan jumlah item 28 item yang masing-masing dimensi terwakili dengan 7 item. Setelah data didapatkan maka akan dilakukan analisis data.

Data akan dianalisis menggunakan teknik analisis statistika uji beda nonparametric. Teknik analisa ini bertujuan untuk menguji perbedaan antar dua kelompok data atau lebih dari satu variabel bebas.

Hasil

Subyek dalam penelitian ini yang bersedia mengisi kuesioner penelitian dalam jangka waktu yang ditentukan sebanyak 185 orang. Subyek berusia berkisar dari 18 tahun-40 tahun, pernah bekerja minimal selama 1 tahun, tingkat pendidikan minimal Sekolah Menengah Atas. Subyek penelitian ini berdomisili di beberapa kota/ kabupaten di Sumatera Barat, seperti Padang, Padang Panjang, Bukittinggi, Payakumbuh, Batu Sangkar, Solok, dan Pariaman.

Hasil penelitian menunjukkan gambaran subjek penelitian berdasarkan jenis kepribadian Myers-Brigss terdapat tipe kepribadian yang paling banyak adalah ISTJ sejumlah 39 orang $(21,09 \%)$, ESFJ sejumlah 36 orang $(19,46 \%)$, ISFP sejumlah 24 orang $(12,97 \%)$, ESTJ sejumlah 19 orang $(10,27 \%)$, ESFP sejumlah 15 orang $(8,11 \%)$, ISFJ sejumlah 12 orang $(6,49 \%)$, ENFP sejumlah 10 orang $(5,41 \%)$, ESTP sejumlah 9 orang $(4,86 \%)$, INTJ sejumlah 5 orang $(2,70 \%)$, INFJ sejumlah 4 orang $(2,16 \%)$, INFP sejumlah 3 orang $(1,62 \%)$, ISTP, ENTJ, ENTP dan ENFJ masing-masing 2 orang $(1,08 \%)$, serta INTP sejumlah 1 orang $(0,54 \%)$. 


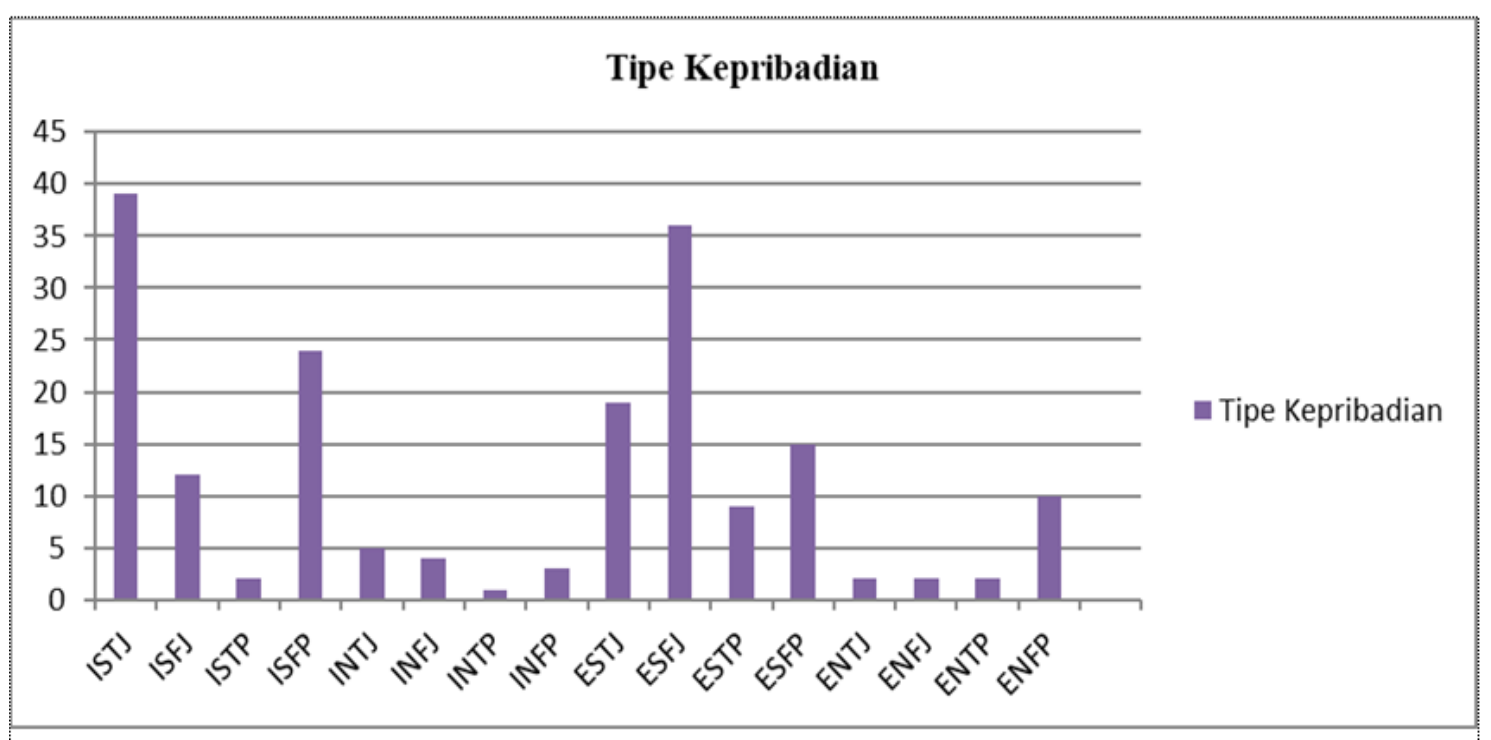

Gambar 1. Diagram Sebaran Jumlah Subjek berdasarkan jenis kepribadian Myers-Brigss

Tabel 1. Kategori Skor Pelecehan seksual di tempat kerja pada wanita etnis Minang

\begin{tabular}{llllll}
\hline & Rumus & Skor & Kategorisasi & F & $\%$ \\
\cline { 2 - 6 } Pelecehan & $(\mu+1,5 \sigma)<X$ & $78<X$ & Sangat Tinggi & 0 & $0 \%$ \\
Seksual & $(\mu+1,5 \sigma)<X \leq(\mu+0,5 \sigma)$ & $78<X \leq 66$ & Tinggi & 46 & $24,86 \%$ \\
di & $(\mu+0,5 \sigma)<X \leq(\mu-0,5 \%)$ & $66<X \leq 54$ & Sedang & 125 & $67,56 \%$ \\
Tempat & $(\mu-0,5 \sigma)<X \leq(\mu-1,5 \%)$ & $54<X \leq 42$ & Rendah & 14 & $7,58 \%$ \\
Kerja & $X \leq(\mu-1,5 \%)$ & $X \leq 42$ & Sangat Rendah & 0 & $0 \%$ \\
& Total & & & 185 & $100 \%$ \\
\hline
\end{tabular}

Tabel diatas menunjukkan bahwa sebagian besar wanita etnis Minang dalam penelitian ini mengalami pelecehan seksual di tempat kerja pada kategori sedang yaitu sejumlah $67,56 \%$, kemudian pada kategori tinggi sejumlah $24,86 \%$ dan pada kategori rendah sejumlah $7,58 \%$.

Selanjutnya hasil kategorisasi skor secara umum pelecehan seksual berdasarkan dimensi Gender Harassement dan Unwanted Sexual Attention pada wanita etnis Minang di tempat kerja termasuk dalam ketegori tinggi, sedangkaan pada dimensi sexual coersioni secara umum subjek termasuk dalam ketegori sedang. Hasil penelitian juga menunjukkan seluruh tipe kepribadian Myers Brigss baik itu tipe ISTJ, ISFJ, ISTP, ISFP, INTJ, INFJ, INTP, INFP, ESTJ, ESFJ, ESTP, ESFP, ENTJ, ENFJ, ENTP dan
ENFP cenderung mengalami pelecehan seksual di tempat kerja pada kategori sedang.

Pengujian normalitas uji normalitas sebaran variabel adversity quotient diperoleh nilai Kolmogorov Smirnov dan nilai Asym.sig. Nilai asym.sig variabel pelecehan seksual dan keenam belas tipe kepribadian Myers Brigss lebih tinggi daripada 0.05 yaitu $0,752>0,05$. Ini berarti data dalam penelitian terdistribusi normal. Uji homogenitas dalam penelitian ini menggunakan model statistik homogenity of varians, diperoleh $\mathrm{p}=0,013(\mathrm{p}<0,05)$.

Berdasarkan hasil tersebut artinya bahwa varian data bersifat tidak homogen. Dikarenakan uji hipotesis pada penelitian ini menggunakan uji beda Kruskal Wallis Test. Dari analisis data diperoleh angka 
signifikansi 0,052 . Artinya $\mathrm{Ha}$ ditolak dan HO diterima yang menunjukkan bahwa tidak terdapat perbedaan yang signifikan pada tingkat pelecehan seksual yang dialami wanita etnis Minang di tempat kerja ditinjau dari tipe kepribadiannya.

\section{Pembahasan}

Penelitian ini bertujuan untuk mengetahui gambaran pelecehan seksual di tempat kerja yang dialami wanita etnis Minang di Sumatera Barat dan mengetahui kecenderungan tipe kepribadian pada wanita etnis Minang yang mengalami pelecehan seksual di tempat kerja tersebut. Dari hasil penelitian, diketahui bahwa tingkat pelecehan seksual di tempat kerja yang dialami wanita etnis Minang ini berada pada kategori sedang yaitu sejumlah 62,56\%.

Pelecehan seksual di tempat kerja seksual adalah semua tindakan seksual atau kecenderungan bertindak secara seksual yang dilakukan oleh seseorang atau kelompok terhadap orang atau kelompok lain, baik secara verbal maupun non verbal yang terjadi dalam lingkup situasi pekerjaan. The Equal Employment Opportunity Commision (The EEOC) menggambarkan pelecehan seksual dalam tiga bentuk yakni: rayuan, permintaan dan tingkah laku atau perkataan yang mengandung unsur seksual, yang menyebabkan korban/ penerima perlakuan merasakan ketidaknyamanan, terganggu, rasa takut dan terancam (Coller, 1998). Dari data penelitian, diketahui bahwa kategori pelecehan seksual di tempat kerja yang dialami wanita etnis Minang berada pada kategori sedang, artinya ia sering mengalami pelecehan seksual di tempat kerja dalam bentuk perilaku fisik yang bersifat seksual seperti sentuhan yang tidak dinginkan (mencium, menepuk, mencubit, mencolek, dan memegang bagian tubuh).

Secara verbal seperti komentarkomentar tentang kehidupan seksual, komentar mengenai anggota tubuh/ penampilan, lelucon dan godaan yang mengandung unsur seksual, dengan bahasa tubuh atau gerak-gerik yang menjurus pada hal yang berunsur seksual seperti mengedip- ngedipkan mata, menggerakkan bibir dan lidah, serta jari-jemari, secara tertulis dan menggunakan gambar/ visual seperti pemaparan gambar atau foto yang berkonotasi seksual, melalui sosial media, pesan pendek dan media komunikasi lainnya, secara psikologis seperti undangan yang tidak diinginkan untuk pergi berkencan, penghinaan, ejekan dan sindiran yang bermuatan seksual.

Ada tiga dimensi yang saling berkaitan dalam perilaku pelecehan seksual, yaitu perilaku pelecehan seksual yang mengarah pada perilaku merendahkan atau menghina seseorang dikarenakan faktor gender seseorang disebut dengan gender harassement; perilaku untuk menarik perhatian orang lain yang mengandung unsur seksual yang tidak dinginkan oleh orang yang dituju disebut dengan unwanted sexual attention; dan perilaku memaksa, memeras atau memberikan iming-iming atau hadiah untuk melakukan aktivitas seksual bersama disebut dengan Sexual Coersion (Fitzgerald, et.all, 1999). Hasil penelitian pada wanita etnis Minang ini menunjukkan tingkat yang berbeda pada dimensi-dimensi tersebut. Dimensi sexual coersion merupakan dimensi yang memiliki tingkat lebih rendah dibandingkan dua dimensi lainnya, Gender Harassement dan Unwanted sexual attention.

Hal ini berarti bahwa wanita etnis Minang di tempat kerja lebih sering mengalami pelecehan seksual seperti mendapatkan komentar yang tidak menyenangkan tentang penampilan tubuh atau aktivitas seksual, mendengarkan pelaku berbicara dan bercanda hal-hal yang mengarah pada unsur seksual atau mesum, dipanggil dengan menggunakan pangilan sayang/ mesra, mendapatkan tatapan yang membuat tidak nyaman karena bermuatan nafsu dan tidak sepantasnya tertuju pada bagian tubuh yang sensitif seperti payudara, paha, pinggul, mendapatkan sentuhan yang tidak diinginkan pada bagian tubuh seperti pundak, punggung, pinggang dan pinggul, yang merupakan bentuk-bentuk perilaku unwanted sexual attention dan gender 
harassment dibandingkan pelecehan seksual dalam bentuk melibatkan dalam pembicaraan tentang seks di luar kemauan seperti membicarakan kehidupan seksual si pelaku ataupun subyek, mendapatkan tontonan gerakan tubuh yang mesum atau cabul dari pelaku pada subyek, mendapatkan perlakuan buruk dan diancam karena menolak melakukan hubungan seksual seperti yang diinginkan pelaku, yang merupakan bentuk perilaku sexual coercion[11].

Berdasarkan penjelasan dari tiga dimensi di atas, walaupun tingkat pelecehan seksual yang dialami wanita etnis Minang pada dimensi sexual coercion berada pada kategori sedang, tidak seperti dimensi unwanted sexual attention dan gender harassment yang berada pada kategori tinggi, namun perlu diupayakan agar perilaku pelecehan seksual di tempat kerja yang dialami wanita etnis Minang dapat diturunkan secara maksimal pada ketiga dimensi ini.

Hal tersebut akan berdampak buruk pada korban pelecehan seksual baik wanita maupun pria. Margaretha (Margaretha, 2015). mengatakan pelecehan seksual akan berpengartuh terhadap fisik juga emosional seperti depresi, mudah marah, gangguan tidur, menunjukkan sikap bermusuhan pada rekan kerja, berbagai ciri stres kerja.

Dampak lain juga dapat dirasakan oleh perusahaan, seperti kerugian materil dan immateril, karena penurunan motivasi dan semangat kerja pada wanita yang mengalami pelecehan seksual ataupun pada rekan kerjanya yang mengetahui kejadian tersebut, menurunnya tingkat presensi hingga pengunduran diri pada wanita yang mengalami pelecehan tersebut, memperburuk standar dan nilai dalam perusahaan bahkan citra perusahaan di mata masyarakat, hingga ada yang berakhir di jalur hukum.

Hasil penelitian ini mendapatkan hasil bahwa tipe kepribadian yang paling banyak ditemui dari wanita etnis Minang yang mengalami pelecehan seksual di tempat kerja adalah ISTJ sejumlah 39 orang
(21,09\%), kemudian ESFJ sejumlah 36 orang $(19,46 \%)$, ISFP sejumlah 24 orang $(12,97 \%)$, ESTJ sejumlah 19 orang $(10,27 \%)$, ESFP sejumlah 15 orang $(8,11 \%)$, ISFJ sejumlah 12 orang (6,49\%), ENFP sejumlah 10 orang $(5,47 \%)$, ESTP sejumlah 9 orang $(4,86 \%)$, INTJ sejumlah 5 orang $(2,70 \%)$, INFJ sejumlah 4 orang $(2,16 \%)$, INFP sejumlah 3 orang $(1,62 \%)$, ISTP, ENTJ, ENTP dan ENFJ masing-masing 2 orang $(1,08 \%)$, serta INTP sejumlah 1 orang $(0,54 \%)$.

Meskipun tipe ISTJ merupakan kecenderungan tipe kepribadian yang lebih sering muncul pada wanita etnis Minang yang mengalami pelecehan seksual di tempat kerja, namun wanita etnis Minang yang mengalami pelecehan seksual di tempat kerja dengan frekuensi yang lebih tinggi dibandingkan yang lain adalah yang memiliki kepribadian ISFJ, ISFP, ESFJ, ESTP dan ESFP.

Tipe-tipe kepribadian Myers Brigss yang berjumlah enam belas tipe ini, masingmasing tipe kepribadiannya memiliki karakteristik/ ciri perilaku yang berbeda. Wanita etnis Minang yang memiliki tipe kepribadian ISTJ akan cenderung menampilkan perilaku serius, tenang, stabil dan damai, ia senang pada fakta, logis, obyektif, praktis dan realistis, ia tipikal task oriented, tekun, teratur, menepati janji, dapat diandalkan dan bertanggung jawab, ia seorang pendengar yang baik, setia, dan hanya mau berbagi dengan orang dekat, ia teguh memegang aturan, standar dan prosedur.

Wanita etnis Minang yang memiliki tipe kepribadian ISFJ akan cenderung menampilkan perilaku yang penuh pertimbangan, hati-hati, teliti dan akurat, ia serius, tenang, stabil namun sensitive, ia ramah, perhatian pada perasaan dan kebutuhan orang lain, setia, kooperatif, serta pendengar yang baik (MBTI, 2018). Wanita etnis Minang yang memiliki tipe kepribadian ISTP akan cenderung menampilkan perilaku yang tenang, pendiam, cenderung kaku, dingin, hati-hati, penuh pertimbangan, logis, rasional, kritis, obyektif, serta mampu 
mengesampingkan perasaan, ia mampu menghadapi perubahan mendadak dengan cepat dan tenang, serta tampil percaya diri, tegas dan mampu menghadapi perbedaan maupun kritik.

Wanita etnis Minang yang memiliki tipe kepribadian ISFP akan cenderung menampilkan perilaku yang praktis, berpikiran simpel fleksibel, ia sensitif, ramah, tidak menonjolkan diri, dan rendah hati pada kemampuannya, ia cenderung menghindari konflik, tidak memaksakan pendapat atau nilai-nilainya pada orang lain, ia biasanya tidak mau memimpin tetapi menjadi pengikut dan pelaksana yang setia.

Wanita etnis Minang yang memiliki tipe kepribadian INFJ akan cenderung menampilkan perilaku yang perhatian pada orang lain, empati, sensitif dan berkomitmen, ia menjadi sukses karena ketekunan, originalitas dan keinginan kuat untuk melakukan apa saja yang diperlukan termasuk memberikan yg terbaik dalam pekerjaannya, ia idealis, perfeksionis, dan memegang teguh prinsipnya.

Wanita etnis Minang yang memiliki tipe kepribadian INTJ akan cenderung menampilkan perilaku yang mandiri dan percaya diri, ia punya kemampuan analisa yang bagus serta menyederhanakan sesuatu yang rumit dan abstrak menjadi sesuatu yang praktis, mudah dipahami dan dipraktekkan, ia juga tipikal yang skeptis, kritis, logis, dan kadang keras kepala.

Wanita etnis Minang yang memiliki tipe kepribadian INFP akan cenderung menampilkan perilaku yang sangat perhatian dan peka dengan perasaan orang lain, ia penuh dengan antusiasme dan kesetiaan, tapi biasanya hanya untuk orang dekat, ia peduli pada banyak hal, ia cenderung idealis dan perfeksionis, ia mempercayai dan mengoptimalkan orang lain.

Wanita etnis Minang yang memiliki tipe kepribadian INTP akan cenderung menampilkan perilaku yang sangat menghargai intelektualitas dan pengetahuan, ia seringkali hanya diam dan menahan diri, ia lebih suka bekerja sendiri, ia cenderung kritis, skeptis, mudah curiga dan pesimis, dan ia tidak suka memimpin dan bisa menjadi pengikut yang tidak banyak menuntut (MBTI, 2018). Wanita etnis Minang yang memiliki tipe kepribadian ESTP akan cenderung menampilkan perilaku yang spontan, aktif, enerjik, cekatan, dan menyenangkan, ia ceplas ceplos, berkarisma, ia menikmati apapun yang terjadi, ia mudah beradaptasi, toleran, pada umumnya konservatif tentang nilainilai. Wanita etnis Minang yang memiliki tipe kepribadian ESFP akan cenderung menampilkan perilaku yang mudah berteman, bersahabat, sangat sosial, ramah, hangat, dan menyenangkan, ia menghibur dan suka menjadi perhatian, ia mudah simpatik dan mengenali perasaan orang lain, ia menghindari konflik dan menjaga keharmonisan suatu hubungan.

Wanita etnis Minang yang memiliki tipe kepribadian ENFP akan cenderung menampilkan perilaku yang ramah, hangat, enerjik, optimis, antusias, dan semangat tinggi, ia penuh ide, ia mampu beradaptasi dengan beragam situasi dan perubahan, ia pandai berkomunikasi, senang bersosialisasi dan membawa suasana positif, ia bisa membaca perasaan orang lain.

Wanita etnis Minang yang memiliki tipe kepribadian ENTP akan cenderung menampilkan perilaku yang gesit, kreatif, inovatif, cerdik, logis, baik dalam melakukan banyak hal, ia banyak bicara dan punya kemampuan debat yang baik, ia bisa berargumentasi untuk senang-senang saja tanpa merasa bersalah, ia tipikal yang fleksibel dan kurang konsisten (MBTI, 2018). Wanita etnis Minang yang memiliki tipe kepribadian ESTJ akan cenderung menampilkan perilaku yang praktis, realistis, berpegang pada fakta, ia sangat sistematis dan terencana, ia konservatif dan cenderung kaku, ia tidak tertarik pada sesuatu yang tidak berguna baginya, tapi dapat menyesuaikan diri jika diperlukan.

Wanita etnis Minang yang memiliki tipe kepribadian ESFJ akan cenderung menampilkan perilaku yang hangat, banyak bicara, ia populer dan aktif dalam aktivitas kelompok, ia selalu melakukan sesuatu yang 
manis bagi orang lain, ia santai, sederhana dan tidak berpikir panjang.

Wanita etnis Minang yang memiliki tipe kepribadian ENFJ akan cenderung menampilkan perilaku yang imajinatif, peka, sensitive dan loyal, ia umumnya peduli pada apa kata orang atau apa yang orang lain inginkan dan cenderung melakukan sesuatu dengan memperhatikan perasaan orang lain, ia pandai bergaul, ramah, dan simpatik, ia butuh apresiasi dan penerimaan dari lingkungannya. Wanita etnis Minang yang memiliki tipe kepribadian ENTJ akan cenderung menampilkan perilaku yang tegas, asertif, terus terang, kritis, dan punya standar tinggi, ia cenderung dominan, kuat kemauannya, perfeksionis dan kompetitif, ia cenderung menutupi perasaan dan menyembunyikan kelemahan, ia memiliki kemampuan komunikasi yang baik (MBTI, 2018). Dari hasil uji hipotesis diketahui bahwa tidak terdapat perbedaan yang signifikan pada tingkat pelecehan seksual yang dialami wanita etnis Minang di tempat kerja ditinjau dari tipe kepribadiannya. Walaupun dari paparan di atas diketahui bahwa masing-masing tipe kepribadian memiliki ciri perilakunya sendiri. Ini menunjukkan bahwa wanita Minang mengalami pelecehan seksual di tempat kerjanya bukan dikarenakan ia memiliki kecenderungan tipe kepribadian tertentu, namun disebabkan oleh berbagai faktor lainnya.

\section{Kesimpulan}

Berdasarkan hasil penelitian dan pengujian hipotesis, maka dapat diambil kesimpulan diantaranya: Tingkat pelecehan seksual di tempat kerja yang dialami wanita etnis Minang berada pada kategori sedang. Tidak terdapat tingkat pelecehan seksual di tempat kerja yang dialami wanita etnis Minang berdasarkan tipologi kepribadian yang dimiliki.

\section{Saran}

Bagi wanita etnis Minang disarankan untuk dapat lebih meningkatkan kehati-hatiannya dalam menjalin relasi di tempat kerja, serta meningkatkan wawasan mengenai bentuk-bentuk pelecehan seksual dan cara untuk meminimalisir hal itu terjadi pada diri sendiri. Bagi pemilik tempat kerja diharapkan memiliki regulasi yang jelas dan tegas terhadap perilaku pelecehan seksual dalam lingkup ruang kerja. Penelitian berikutnya disarankan melanjutkan penelitian terkait tema pelecehan seksual pada wanita etnis Minang dengan menggunakan variabel-variabel lain yang diasumsikan berhubungan dengan perilaku pelecehan seksual.

\section{Daftar Pustaka}

Awaliyah, G., \& Noroyo, B. (2019). 10 juta orang mengalami pelecehan seksual di tempat kerja. Retreived from: Republica.co.id.

Sihite, R. (2007). Perempuan, kesetaraan, \& keadilan suatu tinjaun berwawasan gender. Raja grafindo Persada: Jakarta.

Dwiyanti, F. (2014). Pelecehan seksual pada perempuan di tempat kerja (studi kasus kantor satpol pp provinsi DKI Jakarta. Journal of kriminology indonesia. 10(1). 29-36.

Margaretha. (2015). Pelecahan seksual di tempat kerja. retreived from: http://psikologiforensik.com

Nurvitasari, A. (2018). $81 \%$ responden alami pelecehan seksual di tempat kerja. retreived from: https://magdalene.co/story/surveinever-okay-81-responden-alamipelecehan-seksual-di-tempat-kerja.

Levay, S., \& Valente, M. (2006). Human sexuality, 2nd ed. Sinaver associates: USA.

Winarsusnu, T. (2008). Keselamatan kerja. UMM PRESS: Malang.

Collier, R. (1998). Pelecehan seksual: Hubungan dominasi mayoritas dan minoritas. Tiara wacana: Yogyakarta. 
Primanita, Nio, Yuliani

Santrock, J. (2013). Life-span development. Erlangga: Jakarta.

Fitzgerald, Louise F., Vicki J., Fritz Drasgow, \& Craig R. Waldo. (1999). Measuring sexual harassment in the military : The sexual experiences questionnaire (SEQ - DoD). Military psychology. Vol 11 (3), Page 243 263.

Meyer,M., Berchtold, I., Oestrich,J \& Collins, F. (1987). Sexual Harassment. Princeton Petrocelly : New York.

The Myers and Briggs Foundation. (2018).
"My mbti personality type,".
retreived
from:
www.myersbriggs.org. 